\title{
Pemahaman Perpajakan dan Religiusitas Memoderasi Penurunan Tarif Pajak dan Pelayanan Online pada Kepatuhan Wajib Pajak
}

\author{
I Made Dwi Sumba Wirawan ${ }^{1}$ \\ Sekolah Vokasi D4 Akuntansi \\ Perpajakan Universitas Warmadewa, \\ Indonesia
}

\author{
Gede Yohanes Arygunartha ${ }^{2}$ \\ Sekolah Vokasi D4 Akuntansi \\ Perpajakan Universitas Warmadewa, \\ Indonesia
}

\author{
Desak Rurik Pradnya Paramitha $\mathrm{Nida}^{3}$ \\ Sekolah Vokasi D4 Akuntansi \\ Perpajakan Universitas Warmadewa, Indonesia
}

\begin{abstract}
Surel : dwiisumba@gmail.com
Penelitian ini menguji pengaruh penurunan tarif pajak dan pelayanan online pada kepatuhan wajib pajak serta menguji kemampuan pemahaman perpajakan dan religiusitas sebagai variabel pemoderasi. Jumlah sampel yang dianalisis sebanyak 83 Usaha Mikro, Kecil, dan Menengah (UMKM) yang menjadi mitra Dinas Koperasi dan UMKM Kota Denpasar. Penentuan sampel dalam penelitian ini menggunakan probability sampling dengan metode simple random sampling. Teknik analisis yang digunakan adalah regresi linear berganda dan Moderated Regression Analysis (MRA). Hasil analisis menunjukkan bahwa penurunan tarif pajak dan pelayanan online berpengaruh positif pada kepatuhan wajib pajak. Pemahaman perpajakan dan religiuisitas memperkuat penurunan tarif pajak pada kepatuhan wajib pajak. Namun, pemahaman perpajakan serta religiuisitas tidak memoderasi pengaruh pelayanan online pada kepatuhan wajib pajak.
\end{abstract}

Kata Kunci: Penurunan Tarif Pajak; Pelayanan Online; Kepatuhan; Pemahaman; Religiusitas.

\section{Understanding of Taxation and Religiosity to Moderate the Decrease in Tax Rates and Online Services on Taxpayer Compliance}

\section{ABSTRACT}

This study examines the effect of lowering tax rates and online services on taxpayer compliance and tests the ability to understand taxation and religiosity as moderating variables. The number of samples analyzed was 83 Micro, Small, and Medium Enterprises (MSMEs) which became partners of the Denpasar City Cooperative and UMKM Office. Determination of the sample in this study using probability sampling with simple random sampling method. The analysis technique used is multiple linear regression and Moderated Regression Analysis (MRA). The results of the analysis show that the reduction in tax rates and online services has a positive effect on taxpayer compliance. Understanding taxation and religiosity strengthens the reduction in tax rates on taxpayer compliance. However, understanding taxation and religiosity do not moderate the effect of online services on taxpayer compliance.

Keywords: $\quad$ Reduction In Tax Rates; Online Services; Obedience; Understanding; Religiosity.

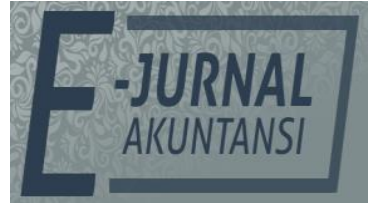

e-ISSN 2302-8556

Vol. 31 No. 5

Denpasar, Mei 2021

Hal. 1169-1188

DOI:

10.24843/EJA.2021.v31.i05.p08

PENGUTIPAN:

Wirawan, I M.D.S.,

Arygunartha, G.Y., \& Nida,

D.R.P.P. (2021). Pemahaman

Perpajakan dan Religiusitas Memoderasi Penurunan Tarif

Pajak dan Pelayanan Online pada Kepatuhan Wajib Pajak.

E-Jurnal Akuntansi, 31(5),

1169-1188

RIWAYAT ARTIKEL:

Artikel Masuk:

15 Desember 2020

Artikel Diterima: 24 Mei 2021

Artikel dapat diakses : https://ojs.unud.ac.id/index.php/Akuntansi/index 


\section{PENDAHULUAN}

Indonesia merupakan negara yang mengandalkan pendapatan dari sektor pajak. Pajak merupakan sumber pendapatan Negara paling besar tanpa adanya penerimaan ajak, Negara akan mengalami permasalahan dalam pembangunan dan permasalahan dalam mensejahterakan rakyatnya (Nadhor et al., 2020). Undang - Undang Nomor 28 tahun 2007 tentang Ketentuan Umum dan Tata Cara Perpajakan menyatakan bahwa pajak merupakan kontribusi wajib yang harus diberikan kepada Negara oleh orang pribadi atau badan yang bersifat memaksa berdasarkan undang-undang yang berlaku, tidak mendapat imbalan secara langsung dan digunakan untuk keperluan Negara yang bertujuan untuk kemakmuran rakyat. Total pendapatan Indonesia menunjukkan bahwa 76 persen pendapatan berasal dari sektor pajak (total pendapatan Rp1.806.520.138.549.830,sedangkan dari sektor pajak Rp1.363.122.621.463.588,- LKPP, 2017).

Perkembangan yang pesat pada pertumbuhan UMKM di Indonesia menyebabkan pemerintah mulai memperhatikan sektor usaha mikro kecil dan menengah (UMKM). Berdasarkan statistik UMKM dari Kementerian Koperasi dan UKM (2012), sumbangan PDB (Produk Domestik Bruto) UMKM pada tahun 2012 sebesar 4.869.568,1 Milyar Rupiah (Zelmiyanti \& Suwardi, 2019). Pendapatan dari PDB akan berhubungan dengan jumlah potensi pajak yang akan diterima negara, sehingga UMKM memiliki potensi pendapatan pajak yang cukup besar sebagai penyumbang pendapatan negara.

Beberapa penelitian terdahulu menjelaskan beberapa keunggulan UMKM. Campin et al. (2013) menyatakan bahwa UMKM memiliki potensi untuk meningkatkan kesejahteraan masyarakat. Hasil penelitian yang dilakukan oleh Hendricks et al. (1997) menjelaskan bahwa pertumbuhan UMKM lebih besar dibanding perusahaan besar. Keunggulan lain dari UMKM adalah menciptakan lapangan pekerjaan baru (Chen et al., 2002) dan (Praag \& Versloot, 2007). Menurut Ananda et al. (2015) bahwa UMKM memberikan kontribusi pada pembangunan dan pertumbuhan ekonomi, tidak hanya di negara-negara yang sedang berkembang, seperti Indonesia, tetapi juga di negara-negara maju.

Tax ratio merupakan perbandingan antara jumlah penerimaan pajak dibandingkan dengan produk domestik bruto (PDB) suatu negara (Sari, 2017). Pada tahun 2018, dibandingkan dengan negara-negara Asia Tenggara tax ratio di Indonesia termasuk yang terendah dibandingkan dengan Malaysia (13,8 persen), Singapura (14,3persen), Filipina (13,7 persen), Kamboja (15,3 persen), dan Thailand (15,7 persen) (Kementerian Keuangan Republik Indonesia, 2019). Nilai tax ratio di Indonesia tahun 2015 sampai dengan 2019 tersaji pada Tabel 1.

Tabel 1. Tax Ratio Indonesia Periode Tahun 2015 - 2019

\begin{tabular}{cc}
\hline Tahun & Tax Ratio (persen) \\
\hline 2015 & 11,6 \\
2016 & 10,8 \\
2017 & 10,7 \\
2018 & 11,5 \\
2019 & 11,9 \\
\hline
\end{tabular}

Sumber: Kementerian Keuangan Republik Indonesia, 2019

Berdasarkan Tabel 1, dapat diamati bahwa tax ratio di Indonesia mengalami fluktuasi, namun masih rendah dibandingkan negara - negara Asia 
Tenggara yang memiliki company size yang serupa di Tahun 2018. Tahun 2015 persentase tax ratio hanya 11,6 persen turun pada tahun 2016 sebesar 10,8 persen, tahun 2017 sebesar 10,7 persen, naik di tahun 2018 sebesar 11,5 persen dan tahun 2019 sebesar 11,9 persen. Kondisi ini dirasa tidak relevan dengan tingkat pertumbuhan usaha di Indonesia, terutama sektor Usaha Mikro, Kecil dan Menengah (UMKM) (Ananda et al., 2015). Jumlah unit usaha di Indonesia dapat kita cermati pada Tabel 2 .

Tabel 2. Jumlah Unit Usaha di Indonesia

\begin{tabular}{crc}
\hline \multirow{2}{*}{ Tahun } & \multicolumn{2}{c}{ Unit Usaha } \\
\cline { 2 - 3 } & UMKM & Usaha Besar \\
\hline 2015 & 59.262 .772 & 4.987 \\
2016 & 61.651 .177 & 5.370 \\
2017 & 62.922 .617 & 5.460 \\
& 64.194 .057 & 5.550 \\
\hline
\end{tabular}

Sumber: Kementerian Koperasi dan Usaha Mikro Kecil dan Menengah Republik Indonesia (2019)

UMKM merupakan jenis usaha dengan jumlah yang dominan dibandingkan dengan jenis usaha besar. Potensi pendapatan UMKM di Indonesia ternyata tidak sebanding dengan pajak yang diterima negara dari sektor UMKM. Kementerian Koperasi dan usaha kecil menengah pada tahun 2017 mencatat ada sebanyak 62.922.617 pelaku usaha UMKM yang ada di Indonesia.Angka tersebut masih jauh dari potensi pajak UMKM, sehingga membuktikan rendahnya tingkat kepatuhan pengusaha UMKM membayar pajak.

Denpasar merupakan salah satu kota yang ada di Indonesia dan Provinsi Bali dengan penyebaran Usaha Mikro, Kecil, Menengah (UMKM) yang cukup banyak yaitu sebesar 31.826 atau sebesar 10,16 persen dari keseluruhan UMKM di Provinsi Bali pada Desember 2017. Pada kantor pelayanan pajak Denpasar Barat tingkat kepatuhan wajib pajak UMKM belum maksimal (Widiasih \& Wiagustini, 2019). Pada tahun 2015 jumlah UMKM yang terdaftar sebanyak 11.925. Namun kontribusi UMKM, dalam pembayaran pajak masih rendah. Rata - rata kontribusi UMKM dalam pembayaran pajak pada dua KPP di Kota Denpasar sebesar 3,5 persen dari seluruh penerimaan pada dua KPP yaitu KPP Denpasar Timur dan KPP Denpasar Barat. Sedangkan UMKM yang terdaftar sebagai wajib pajak pada dua KPP sampai dengan tahun 2015 sebanyak 10.746, ini berarti masih ada 1.179 UMKM yang belum terdaftar sebagai wajib pajak (Supadmi \& Suputra, 2016). Hal ini mengindikasikan belum maksimalnya proses sosialisasi dan edukasi kepada masyarakat atas pemberlakuan suatu undang undang di bidang perpajakan. Molero \& Pujol (2012) menyatakan alasan pengusaha tidak membayar pajak karena manfaat yang dirasakan tidak sebanding dengan biaya yang dikeluarkan. Kamleitner et al. (2012) menemukan ada tiga aspek kunci yang menyebabkan rendahnya tingkat kepatuhan pajak UMKM. Pertama, pemilik usaha kecil cenderung melihat lebih banyak kesempatan untuk tidak mematuhi dibandingkan pekerja. Kedua, kurangnya pengetahuan pajak bagi pengusaha kecil. Dan ketiga, persepsi pengusaha UMKM bahwa membayar pajak merupakan suatu beban yang mengurangi keuntungan. 
Teori perilaku terencana (theory of planned behavior) memandang bahwa perilaku seseorang dipengaruhi oleh niat seseorang (behavioral intention) untuk melakukan atau tidak melakukan suatu perilaku. Hal ini dikarenakan niat dalam berperilaku merupakan motivasi yang akhirnya akan mempengaruhi perilaku seseorang (Ajzen, 1991). Pemerintah selalu berupaya guna menaikkan pendapatan dari sektor perpajakan maka dikeluarkan undang-undang guna meningkatkan niat dalam berperilaku yang dapat memotivasi para pelaku usaha mikro kecil menengah dengan tujuan mempermudah para pelaku usaha untuk membayar pajak. Peraturan tersebut adalah Peraturan Pemerintah Nomor 46 Tahun 2013 yang di tetapkan pada tanggal 1 Juli 2013 yaitu mengenai penghasilan pajak yang di terima atau di peroleh oleh wajib pajak dengan peredaran bruto tertentu (Anwar \& Syafiqurrahman, 2016). Guna membantu kegiatan ekonomi kecil dan menengah, pemerintah memberikan pelayanan perpajakan untuk Wajib Pajak UMKM dengan tarif pajak 1 persen yang dikenakan pada siklus penjualan bruto sampai dengan Rp 4,8 miliar per tahun. Sedangkan Wajib Pajak UMKM dengan penghasilan bruto di atas Rp 4,8 miliar per tahun dikenakan tarif normal sesuai Pasal 17 Undang-Undang Pajak Penghasilan.

Dalam penerapannya Peraturan Pemerintah Nomor 46 Tahun 2013 menuai pro dan kontra. Aspek keadilan merupakan salah satu kontra yang sering disoroti mengingat pajak penghasilan Peraturan Pemerintah Nomor 46 Tahun 2013 termasuk dalam pajak final yang tidak memandang apakah hasil akhir dari usaha wajib pajak tersebut laba atau rugi, sepanjang wajib pajak memiliki omset maka wajib pajak harus membayar pajak. Pemungutan pajak memang bukan suatu pekerjaan yang mudah, disamping peran serta aktif dari aparat pajak, juga dituntut kemauan dari para wajib pajak itu sendiri untuk mau membayarkan pajak mereka. Kemauan wajib pajak dalam membayar kewajiban perpajakannya merupakan hal penting dalam rangka optimalisasi penerimaan pajak (Ayem \& Nofitasari, 2019).

Guna mensiasati Wajib Pajak UMKM agar mau membayar pajak, telah dirilis Peraturan Pemerintah Nomor 23 Tahun 2018 tentang Pajak Penghasilan atas Penghasilan dari Usaha yang Diterima atau Diperoleh Wajib Pajak yang Memiliki Peredaran Bruto (Omset) Tertentu. Aturan tersebut diperkenalkan sebagai revisi PPh final untuk pelaku UMKM, dari yang tarifnya 1 persen kini menjadi 0,5 persen. Berlakunya Peraturan Pemerintah Nomor 23 Tahun 2018 tersebut resmi mengganti dan mencabut seluruh ketentuan dari aturan yang ada di Peraturan Pemerintah Nomor 46 Tahun 2013. Meskipun pendapatan pemerintah akan berkurang di karenakan penurunan tarif pajak UMKM akan tetapi pemerintah memiliki optimis yang tinggi dengan adanya penurunan tarif tersebut yaitu pemerintah berharap kesadaran wajib pajak UMKM akan meningkat baik dalam membayarkan pajaknya maupun mendaftarkan diri menjadi wajib pajak (Nadhor et al., 2020).

Selain menurunkan tarif pengenaan pajak pemerintah juga memanfaatkan adanya perkembangan teknologi yaitu dengan cara melakukan pembaruan mengenai pelayanan perpajakan yang bisa di lakukan secara online. Dengan adanya kemudahan dalam melakukan pembayaran pajak secara online diharapkan meningkatkan kepatuhan wajib pajak dalam membayar pajak. 
Pemerintah melalui dirjen pajak meluncurkan aplikasi/website guna mempermudah dalam melakukan perpajakan yang akan dilakukan oleh wajib pajak. Wajib pajak bisa memanfaatkan layanan online tersebut yang sudah di sediakan oleh dirjen pajak guna melakukan pengurusan perpajakannya. Pemerintah melalui dirjen pajak mengeluarkan beberapa aplikasi yang bisa dimaanfaatkan dan bisa mempermudah para wajib pajak dalam mengurus perpajakan yaitu aplikasi e-faktur, e-filling dan e-billing. Penelitian ini mengacu kepada penelitian terdahulu yang dilakukan oleh (Gunawan et al. (2014) tentang persepsi wajib pajak mengenai e-filling dan pengaruhnya terhadap tingkat kepatuhan wajib pajak orang pribadi dalam melaporkan pajak, dalam penelitian tersebut menyatakan bahwa kegunaan, kemudahan, kerumitan, keamanan, dan kerahasiaan e-filling berpengaruh secara signifikan terhadap kepatuhan wajib pajak orang pribadi dalam melaporkan pajak.

Hasil penelitian Mustofa et al. (2016) menyatakan bahwa tarif pajak tidak berpengaruh terhadap kepatuhan wajib pajak. Wajib pajak cenderung mengabaikan besarnya tarif pajak. Jika pada dasarnya wajib pajak adalah seseorang yang tidak patuh terhadap kepentingan perpajakan, maka tarif pajak yang rendah pun tidak mempengaruhi tingkat kepatuhannya. Yusro \& Kiswanto (2014) menyatakan bahwa tarif pajak tidak berpengaruh terhadap kepatuhan membayar pajak. Hal ini disebabkan karena kepatuhan dalam membayar pajak UMKM tidak dipengaruhi oleh tarif pajak yang berlaku. Begitu pula dengan pelayanan online, Rachdianti et al. (2016) penggunaan e-Tax tidak memiliki pengaruh yang signifikan terhadap kepatuhan wajib pajak. Pengunaan $e$-Tax ataupun tidak digunakan pembayaran pajak secara online oleh wajib pajak, maka wajib pajak tersebut tetap tidak patuh. Suherman, et al. (2015) menyatakan bahwa penerapan e-filing tidak berpengaruh terhadap kepatuhan Wajib Pajak dapat disebabkan karena masih ada Wajib Pajak yang belum sadar akan kewajiban perpajakannya.

Berdasarkan beberapa penelitian sebelumnya, penurunan tarif dan pelayanan online belum cukup efektif untuk meningkatkan kepatuhan pajak. Teori atribusi menjelaskan bahwa ketika individu mengamati perilaku individu lainnya, individu tersebut berupaya untuk menjelaskan apakah perilaku tersebut disebabkan pihak internal ataupun eksternal (Robbins \& Judge, 2008). Perilaku yang disebabkan secara internal merupakan perilaku yang berada pada tingkah laku pribadi seorang individu sendiri, yang dalam penelitian ini dikaitkan dengan pemahaman perpajakan dan religiusitas. Pemahaman perpajakan menjadi salah satu faktor yang mempengaruhi kepatuhan Wajib Pajak (Ananda et al., 2015). Masih kurangnya kesadaran wajib pajak dalam membayar pajak, tidak terlepas dari faktor pegetahuan dan pemahaman tentang perpajakan itu sendiri (Nugraheni \& Purwanto, 2015). Fahluzy \& Agustina (2014) mendefinisikan pemahaman sebagai keadaan di mana wajib pajak mengerti dengan baik semua hal tentang perpajakan. Sehingga, apabila tingkat pemahaman perpajakan yang dimiliki tinggi, maka tingkat kepatuhan wajib pajak juga akan semakin meningkat.

Selain pemahaman perpajakan, menurut Utama \& Wahyudi (2016) dan Benk et al. (2016) kepatuhan wajib pajak juga dipengaruhi oleh religiusitas. Semua agama di dunia ini memberikan petunjuk yang baik bagi pemeluk 
agamanya dengan menganjurkan untuk berperilaku yang baik dan mematuhi norma norma yang berlaku. Sehingga, tingkat religiusitas yang dimiliki seseorang ini berusaha berperilaku sesuai dengan kaidah norma yang berlaku. Ketika wajib pajak yang memiliki religiusitas yang tinggi, maka ia berusaha untuk patuh terhadap peraturan perpajakan (Utama \& Wahyudi, 2016). Religiusitas merupakan keyakinan yang dimiliki oleh wajib pajak bahwa wajib pajak percaya terhadap Tuhan, dimana wajib pajak takut melakukan pelanggaran peraturan pajak (Basri \& Surya, 2014). Melakukan pelanggaran peraturan perpajakan merupakan perilaku yang tidak etis, karena merugikan Negara. Perilaku tidak etis inilah yang merupakan dimensi dari religiusitas. Sehingga, apabila religiusitas yang dimiliki tinggi, maka tingkat kepatuhan wajib pajak juga akan semakin meningkat.

Berdasarkan latar belakang diatas, adapun rumusan masalah dalam penelitian ini adalah apakah penurunan tarif pajak berpengaruh pada kepatuhan wajib pajak. Apakah pelayanan online berpengaruh pada kepatuhan wajib pajak. Apakah pemahaman perpajakan memperkuat pengaruh penurunan tarif pajak terhadap kepatuhan wajib pajak. Apakah pemahaman perpajakan memperkuat pengaruh pelayanan online terhadap kepatuhan wajib pajak.Apakah religiusitas memperkuat pengaruh penurunan tarif pajak terhadap kepatuhan wajib pajak. Apakah religiusitas memperkuat pengaruh pelayanan online terhadap kepatuhan wajib pajak. Penelitian ini dilakukan pada Wajib Pajak Usaha Mikro, Kecil, dan Menengah (UMKM) yang menjadi mitra Dinas Koperasi dan UMKM Kota Denpasar.

Konsep penelitian merupakan hubungan logis dari landasan teori yang telah dijabarkan. Konsep penelitian tersaji pada Gambar 1.

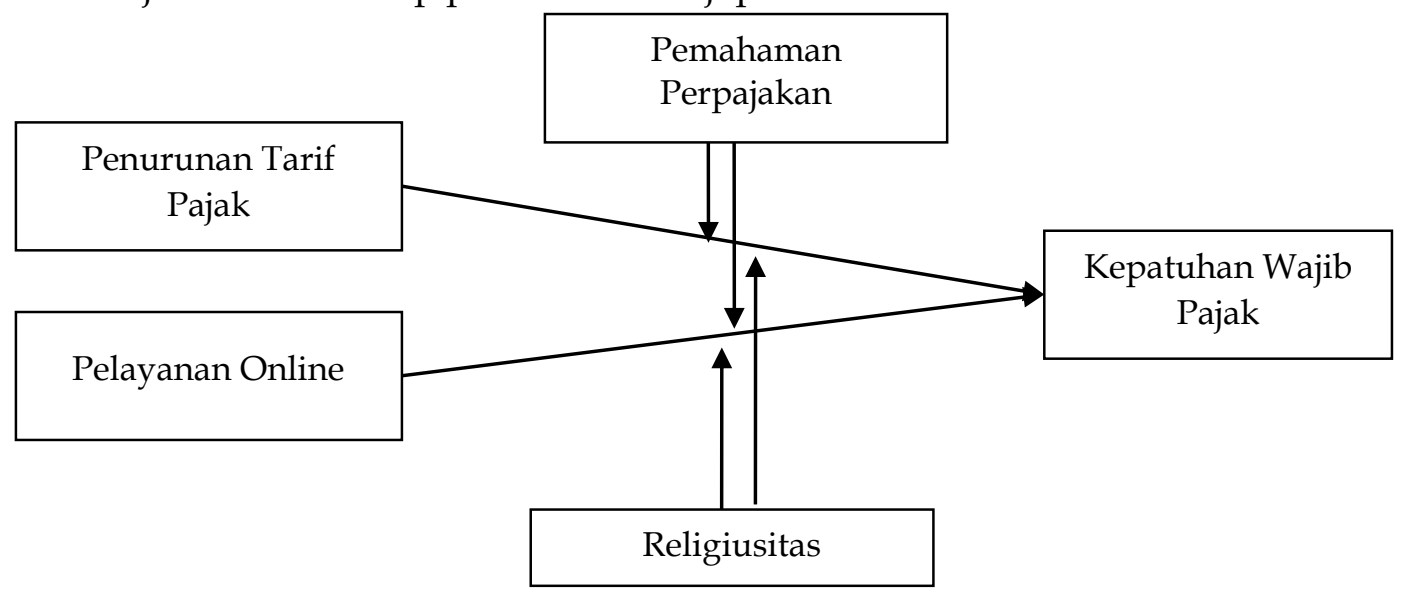

Sumber: Data Penelitian, 2020

Gambar 1. Model Peneltian

Teori perilaku terencana (theory of planned behavior) memandang bahwa perilaku seseorang dipengaruhi oleh niat seseorang (behavioral intention) untuk melakukan atau tidak melakukan suatu perilaku. Hal ini dikarenakan niat dalam berperilaku merupakan motivasi yang akhirnya akan mempengaruhi perilaku seseorang (Ajzen, 1991). Kepatuhan merupakan motivasi seseorang atau kelompok untuk berbuat sesuai peraturan yang sudah ditetapkan. Dalam perpajakan kepatuhan yang dimaksud sesuai dengan peraturan perpajakan yang 
berlaku dalam hal ini adalah sesorang yang patuh akan perundang-undangan mengenai perpajakan (Zuhdi et al., 2015). Penurunan tarif pajak yaitu suatu peraturan perpajakan terbaru yang termuat dalam PP No 23 Tahun 2018, dimana tarif pph final turun menjadi 0,5 persen. Dalam peraturan terbaru pemerintah berharap adanya peningkatan kepatuhan pajak yang dilakukan oleh para pengusaha UMKM yang ada di Indonesia, karena para pelaku usaha UMKM yang ada di Indonesia sangat tinggi dan berpotensi memajukan perokonomian Negara akan tetapi dalam pelaksaan perpajakan para pengusaha UMKM masih terbilang kecil (Nadhor et al., 2020). Mir'atusholihah et al. (2014) yang menyatakan tarif pajak mempunyai pengaruh pada ketaatan wajib pajak UMKM. Penelitian Prawagis et al. (2016) menunjukkan bahwa persepsi tarif pajak mempunyai pengaruh signifikan terhadap ketaatan wajib pajak UMKM. Hipotesis yang diajukan.

$\mathrm{H}_{1}$ : Penurunan tarif pajak berpengaruh positif pada kepatuhan wajib pajak.

Teori Perilaku Terencana (Theory of Planned Behavior) dipergunakan untuk menjelaskan berbagai macam perilaku seseorang. Sikap sebagai kecenderungan psikologi yang diekspresikan dengan mengevaluasi suatu entitas dalam derajat suka atau tidak suka (Eagly \& Chaiken, 2007). Sikap juga ditentukan dengan adanya keyakinan mengenai konsekuensi yang nantinya akan diperoleh dari suatu perilaku individu (Ajzen \& Fishbein, 2005). Kepatuhan perpajakan merupakan tindakan yang dilakukan oleh wajib pajak guna memenuhi kewajiban perpajakannya sesuai dengan ketentuan peraturan perundangundangan yang berlaku di suatu negara. Sehingga, dapat disimpulkan bahwa kepatuhan adalah kondisi di mana wajib pajak akan memenuhi seluruh kewajiban perpajakannya sesuai dengan aturan yang ada (Zuhdi et al., 2015). Pelayanan perpajakan secara online ini dilakukan untuk mempermudah pelaporan pajak yang dapat digunakan sejak pendaftaran sebagai wajib pajak, pelaporan pajak, dan pembayaran pajak. Semua bisa di lakukan dengan cara online. Berikut pajak online yang sudah ada adalah e-faktur, e-filling, e-billing. Peraturan direktur jenderal pajak nomor PER-26/PJ/2014 tentang sistem pembayaran pajak secara elektronik, billing system didefinisikan sebagai metode pembayaran pajak secara elektronik yang memanfaatkan kode billing. Dengan adanya kemudahan dalam melakukan pembayaran pajak secara online diharapkan meningkatkan kepatuhan wajib pajak dalam membayar pajak. Sarunan (2015) yang menyatakan bahwa sistem pelayanan online berpengaruh positif dan signifikan terhadap kepatuhan wajib pajak. Hipotesis yang diajukan. $\mathrm{H}_{2}$ : Pelayanan online berpengaruh positif pada kepatuhan wajib pajak.

Teori atribusi menjelaskan bahwa ketika individu mengamati perilaku individu lainnya, individu tersebut berupaya untuk menjelaskan apakah perilaku tersebut disebabkan pihak internal ataupun eksternal (Robbins \& Judge, 2008). Perilaku yang disebabkan secara internal merupakan perilaku yang berada pada tingkah laku pribadi seorang individu sendiri, yang dalam penelitian ini dikaitkan dengan pemahaman perpajakan. Pemahaman perpajakan menjadi salah satu faktor yang mempengaruhi kepatuhan Wajib Pajak (Ananda et al., 2015). Fahluzy \& Agustina (2014) mendefinisikan pemahaman sebagai keadaan di mana wajib pajak mengerti dengan baik semua hal tentang perpajakan. Sehingga, apabila tingkat pemahaman perpajakan yang dimiliki tinggi, maka 
tingkat kepatuhan wajib pajak juga akan semakin meningkat. Pemahaman perpajakan yang dimiliki oleh Wajib Pajak UMKM diharapkan dapat bersinergi dengan penurunan tarif pajak sehingga akan lebih meningkatkan kepatuhan wajib pajak dalam melakukan kewajiban perpajakannya. Hipotesis yang diajukan.

$\mathrm{H}_{3}$ : Pemahaman perpajakan memperkuat pengaruh penurunan tarif pajak terhadap kepatuhan wajib pajak.

Teori atribusi menjelaskan bahwa ketika individu mengamati perilaku individu lainnya, individu tersebut berupaya untuk menjelaskan apakah perilaku tersebut disebabkan pihak internal ataupun eksternal (Robbins \& Judge, 2008). Proses pemahaman konsep perpajakan tersebut dapat dilakukan melalui pengkajian terhadap aturan - aturan perpajakan yang berlaku. Oladipupo \& Obazee (2016), pemahaman perpajakan adalah tingkat kesadaran dari wajib pajak terhadap undang-undang perpajakan. Nugraheni \& Purwanto (2015) yang menyatakan masih kurangnya kesadaran wajib pajak dalam membayar pajak, tidak terlepas dari faktor pegetahuan dan pemahaman tentang perpajakan itu sendiri. Sehingga dengan pemahaman perpajakan yang dimiliki oleh wajib pajak UMKM dapat bersinergi dengan pelayanan online yang telah difasilitasi oleh pemerintah untuk memudahkan dalam administrasi perpajakan sehingga diharapkan akan meningkatkan kepatuhan wajib pajak UMKM. Adapun hipotesis yang diajukan adalah.

$\mathrm{H}_{4}$ : Pemahaman perpajakan memperkuat pengaruh pelayanan online terhadap kepatuhan wajib pajak.

Robbins \& Judge (2008) menjelaskan teori atribusi menjelaskan tentang individu yang mengamati perilaku individu lainnya, individu tersebut berupaya untuk menjelaskan apakah perilaku tersebut disebabkan pihak internal ataupun eksternal. Perilaku yang disebabkan secara internal merupakan perilaku yang berada pada tingkah laku pribadi seorang individu sendiri, yang dalam penelitian ini dikaitkan dengan religiuisitas. Menurut Utama \& Wahyudi (2016) dan Benk et al. (2016) menyatakan kepatuhan wajib pajak diperngaruhi oleh religiusitas. Semua agama di dunia ini memberikan petunjuk yang baik bagi pemeluk agamanya dengan menganjurkan untuk berperilaku yang baik dan mematuhi norma norma yang berlaku. Sehingga, tingkat religiusitas yang dimiliki seseorang ini berusaha berperilaku sesuai dengan kaidah norma yang berlaku. Sehingga, apabila religiusitas yang dimiliki tinggi, maka tingkat kepatuhan wajib pajak juga akan semakin meningkat karena wajib pajak UMKM akan mengikuti kaidah norma yang berlaku.

$\mathrm{H}_{5}$ : Religiuistas memperkuat pengaruh penurunan tarif pajak terhadap kepatuhan wajib pajak.

Hasil penelitian Benk et al. (2016) dan Utama \& Wahyudi (2016) memberikan hasil bahwa seseorang yaitu wajib pajak yang memiliki tingkat kepercayaan yang tinggi, akan selalu senantiasa taat dan patuh terhadap kewajibannya terhadap peraturan perpajakan. Dengan adanya religiusitas yang tinggi dan penurunan tarif pajak akan mampu meningkatkan kepatuhan wajib pajak UMKM karena penurunan tarif pajak yang disertai dengan motivasi dari dalam diri wajib pajak yaitu kepercayaan yang dimiliki akan menuntun untuk menaati norma yang berlaku. Selain itu, religiusitas yang dimiliki oleh wajib 
pajak UMKM dapat bersinergi dengan pelayanan online yang telah difasilitasi oleh pemerintah untuk memudahkan dalam administrasi perpajakan sehingga diharapkan akan meningkatkan kepatuhan wajib pajak UMKM. Adapun hipotesis yang diajukan adalah.

$\mathrm{H}_{6}$ : Religiuistas memperkuat pengaruh pelayanan online terhadap kepatuhan wajib pajak.

\section{METODE PENELITIAN}

Objek penelitian adalah kepatuhan wajib pajak, populasi sebanyak 32.026 UMKM yang yang menjadi mitra Dinas Koperasi dan UMKM Kota Denpasar. Jumlah UMKM perhitungan sampel dalam penelitian menggunakan rumus Slovin dengan prosentase kelonggaran yang digunakan adalah 10 persen. Penentuan sampel dalam penelitian ini menggunakan probability sampling, sedangkan pengambilan sampelnya menggunakan metode simple random sampling.

Variabel dependen dalam penelitian ini adalah kepatuhan wajib pajak. Kepatuhan wajib pajak adalah sesorang yang patuh akan perundang-undangan mengenai perpajakan (Nadhor et al., 2020). Indikator yang digunakan dalam variabel ini adalah pendaftaran NPWP, pengisian dan pelaporan SPT, perhitungan Pajak Terutang, pembayaran pajak, dan sikap wajib pajak. Variabel kepatuhan wajib pajak diukur dengan mengadopsi instrumen yang dikembangkan oleh Nadhor et al. (2020), dengan delapan butir pernyataan yang diukur dengan skala likert lima poin.

Variabel independen dalam penelitian ini adalah penurunan tarif pajak dan pelayanan online. Penurunan tarif pajak yaitu suatu peraturan perpajakan terbaru yang termuat dalam PP No 23 Tahun 2018, dimana tarif pph final turun menjadi 0,5 persen (Nadhor et al.,2020). Indikator yang digunakan dalam variabel ini adalah sikap wajib pajak setelah adanya penurunan tarif pajak UMKM dan persepsi wajib pajak terhadap penurunan tarif pajak UMKM. Variabel penurunan tarif pajak diukur dengan mengadopsi instrumen yang dikembangkan oleh Nadhor et al. (2020), dengan enam butir pernyataan yang diukur dengan skala likert lima poin.

Pelayanan online yaitu suatu sistem pelayan dalam perpajakan yang dilakukan secara online (Nadhor et al., 2020). Indikator yang digunakan dalam variabel ini adalah sikap wajib pajak dan persepsi wajib pajak tentang pemberlakuan sistem pelayanan online, dan kemudahan e-faktur, e-filling, dan ebilling bagi wajib pajak. Variabel pelayanan online diukur dengan mengadopsi instrumen yang dikembangkan oleh Nadhor et al. (2020), dengan tujuh butir pernyataan yang diukur dengan skala likert lima poin.

Variabel moderasi dalam penelitian ini adalah pemahaman perpajakan dan religiusitas. Pemahaman perpajakan adalah proses dimana wajib pajak mengetahui tentang perpajakan dan mengaplikasikan pengetahuan itu untuk membayar pajak (Adiasa, 2013). Indikator yang digunakan dalam variabel ini adalah mengetahui dan berusaha memahami Undang-undang perpajakan, pengetahuan dan pemahaman mengenai hak dan kewajiban sebagai wajib pajak, pengetahuan dan pemahaman mengenai sanksi perpajakan, pengetahuan dan pemahaman mengenai PTKP, PKP dan tarif pajak, dan wajib pajak mengetahui 
dan memahami peraturan perpajakan melalui sosialisasi yang dilakukan oleh KPP. Variabel pemahaman perpajakan diukur dengan mengadopsi instrumen yang dikembangkan oleh Adiasa (2013), dengan dua belas butir pernyataan yang diukur dengan skala likert lima poin.

Religiusitas merupakan keyakinan yang dimiliki seseorang yang didasari atas kepercayaan yang selalu ia tanamkan dalam dirinya, keyakinan yang membuat seseorang taat dan patuh dalam menjalankan kewajibannya terhadap sesuatu hal yang wajib ia taati dan mematuhinya (Mayasari et al., 2015). Indikator yang digunakan dalam variabel ini adalah kepercayaan yang selalu ia tanamkan dalam dirinya dan keyakinan yang membuat seseorang taat dan patuh dalam menjalankan kewajibannya. Variabel religiusitas diukur dengan mengadopsi instrumen yang dikembangkan oleh Anggraeni (2016), dengan enam butir pernyataan yang diukur dengan skala likert lima poin.

Penelitian ini menggunakan metode analisis data Regresi Linier Berganda dan Moderated Regression Analysis (MRA) dengan bantuan aplikasi stastistik SPSS for Windows. Model regresi linear berganda dalam penelitian ini, dinyatakan dengan persamaan sebagai berikut.

Persamaan 1:

$Y=\alpha+\beta_{1} \cdot X_{1}+\beta_{2} \cdot X_{2}+\varepsilon$

Persamaan 2:

$Y=\alpha+\beta_{1} \cdot X_{1}+\beta_{2} \cdot X_{2}+\beta_{3} \cdot X_{3}+\beta_{5} . X_{1} X_{3}+\beta_{7} \cdot X_{2} X_{3}+\varepsilon$

Persamaan 3:

$Y=\alpha+\beta_{1} . X_{1}+\beta_{2} . X_{2}+\beta_{4} . X_{4}+\beta_{6} . X_{1} X_{4}+\beta_{8} . X_{2} X_{4}+\varepsilon$

Keterangan:

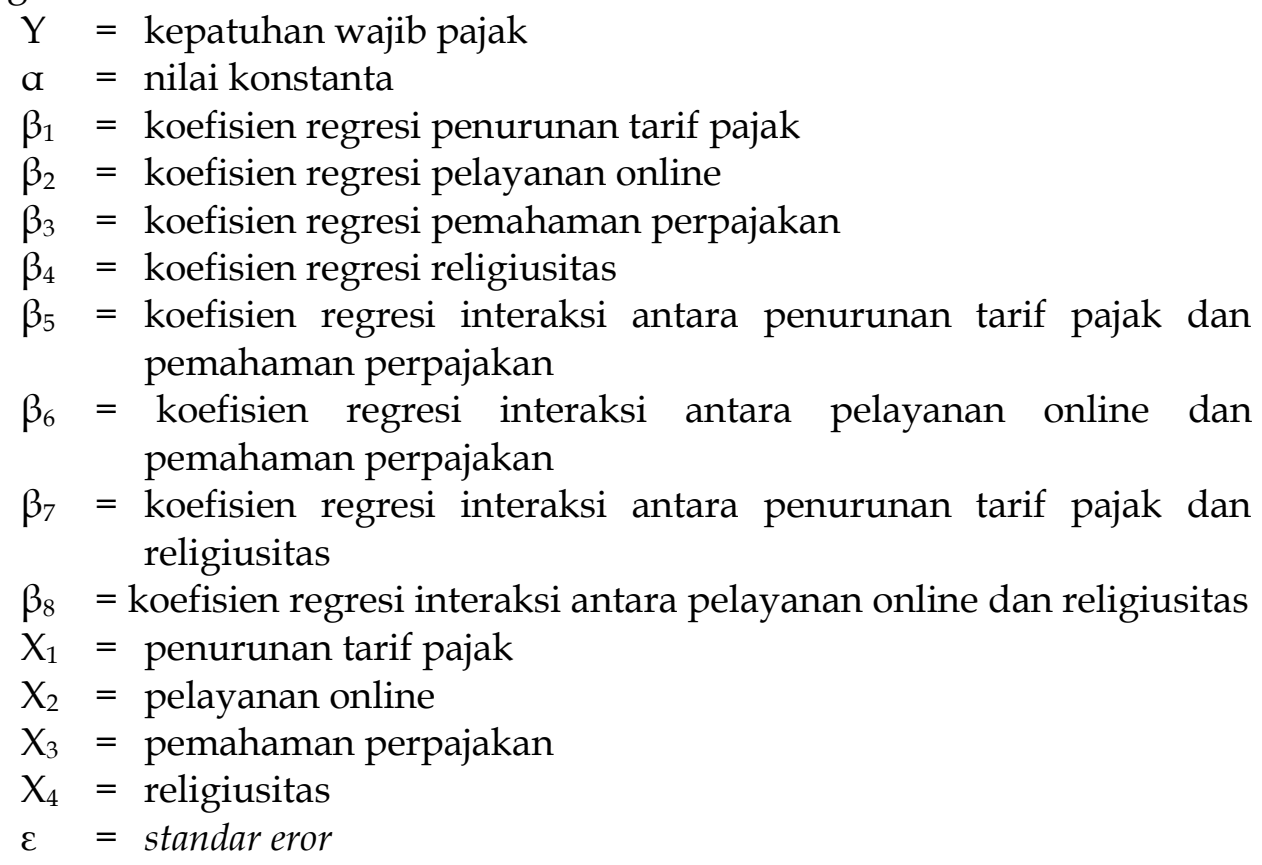

\section{HASIL DAN PEMBAHASAN}

Populasi dalam penelitian ini adalah semua Wajib Pajak Usaha Mikro, Kecil, dan Menengah (UMKM) yang menjadi mitra Dinas Koperasi dan UMKM Kota Denpasar. Jumlah populasi dalam penelitian ini adalah sebanyak 32.026 UMKM. 
Dari 100 kuesioner yang disebarkan, sebanyak 83 kuesioner yang kembali dan layak dianalisis. Jumlah sampel dan tingkat pengembalian dapat dilihat pada Tabel 3, sebagai berikut.

Tabel 3. Tingkat Pengembalian Kuesioner

\begin{tabular}{|c|c|}
\hline Keterangan & Jumlah \\
\hline Kuesioner yang disebar & 100 \\
\hline Kuesioner yang kembali & 83 \\
\hline Tingkat Pengembalian & \\
\hline$\frac{\text { Kuesioner yang dikembalikan }}{\text { Kuesioner yang disebarkan }} \times 100 \%$ & 83 persen \\
\hline
\end{tabular}

Sumber: Data Penelitian, 2020

Pengujian asumsi klasik meliputi uji normalitas, uji multikolinearitas, dan uji heteroskedastisitas. Pengujian asumsi klasik telah memenuhi uji, sehingga model layak digunakan untuk memprediksi. Tabel 4, menunjukkan hasil pengujian regresi linear berganda dengan signifikansi sebesar 5 persen.

Tabel 4. Hasil Uji Regresi Linier Berganda

\begin{tabular}{lcc}
\hline \multicolumn{1}{c}{ Keterangan } & Nilai Beta & Signifikansi \\
\hline (Constant) & 1,110 & 0,537 \\
Penurunan Tarif Pajak & 1,066 & 0,000 \\
Pelayanan Online & 0,267 & 0,032 \\
\hline
\end{tabular}

Sumber: Data Penelitian, 2020

Hipotesis pertama menyatakan bahwa penurunan tarif pajak berpengaruh positif pada kepatuhan wajib pajak. Tabel 4, menunjukkan bahwa hubungan antara penurunan tarif pajak dengan kepatuhan wajib pajak UMKM adalah positif sebesar 1,066 dengan nilai signifikansi 0,000 lebih kecil dari $\alpha=0,05$ yang berarti bahwa secara langsung penurunan tarif pajak berpengaruh positif pada kepatuhan wajib pajak. Berdasarkan hasil penelitian tersebut maka hipotesis pertama diterima. Hal tersebut menunjukkan bahwa semakin meningkat penurunan tarif pajak, maka kepatuhan wajib pajak semakin meningkat.

Penurunan tarif pajak yaitu suatu peraturan perpajakan terbaru yang termuat dalam PP No 23 Tahun 2018, dimana tarif pph final turun menjadi 0,5 persen. Berdasarkan hasil jawaban responden terhadap kuesioner mengenai penurunan tarif perpajakan, didapatkan skor rata-rata tertinggi yaitu 4,46 dari pernyataan "Penurunan tarif pajak, pajak yang saya bayarkan semakin sedikit". Hal tersebut menunjukkan bahwa Wajib Pajak UMKM mengetahui penurunan tarif sesuai PP No. 23 Tahun 2018, penurunan tarif dari 1 persen menjadi 0,5 persen dan dengan penurunan tersebut dapat memotivasi Wajib Pajak untuk taat dalam memenuhi kewajiban perpajakan. Dalam peraturan terbaru pemerintah berharap adanya peningkatan kepatuhan pajak yang dilakukan oleh para pengusaha UMKM yang ada di Indonesia, karena para pelaku usaha UMKM yang ada di Indonesia sangat tinggi dan berpotensi memajukan perokonomian Negara akan tetapi dalam pelaksanaan perpajakan para pengusaha UMKM masih terbilang kecil (Nadhor et al., 2020). Hasil penelitian ini mendukung penelitian Mir'atusholihah et al. (2014) yang menyatakan tarif pajak mempunyai pengaruh pada ketaatan wajib pajak UMKM. Penelitian (Prawagis et al., 2016) 
menunjukkan bahwa persepsi tarif pajak mempunyai pengaruh signifikan terhadap ketaatan wajib pajak UMKM.

Hipotesis kedua menyatakan bahwa pelayanan online berpengaruh positif pada kepatuhan wajib pajak. Tabel 4, menunjukkan bahwa hubungan antara pelayanan online dengan kepatuhan wajib pajak adalah positif sebesar 0,267 dengan nilai signifikansi 0,032 lebih kecil dari $a=0,05$ yang berarti bahwa secara langsung pelayanan online berpengaruh positif pada kepatuhan wajib pajak UMKM. Berdasarkan hasil penelitian tersebut maka hipotesis kedua diterima. Hal tersebut menunjukkan bahwa semakin meningkat pelayanan online, maka kepatuhan wajib pajak semakin meningkat.

Pelayanan perpajakan secara online ini dilakukan untuk mempermudah pelaporan pajak yang dapat digunakan sejak pendaftaran sebagai wajib pajak, pelaporan pajak, dan pembayaran pajak. Semua bisa di lakukan dengan cara online. Berikut pajak online yang sudah ada adalah e-faktur, e-filling, e-billing. Peraturan direktur jenderal pajak nomor PER-26/PJ/2014 tentang sistem pembayaran pajak secara elektronik, billing system didefinisikan sebagai metode pembayaran pajak secara elektronik yang memanfaatkan kode billing. Berdasarkan hasil jawaban responden terhadap kuesioner mengenai pelayanan online, didapatkan skor rata-rata tertinggi yaitu 4,01 dari pernyataan "Pelayanan online menguntungkan saya dalam segi waktu.". Hal tersebut menunjukkan bahwa Wajib Pajak UMKM merasa diuntungkan dengan adanya pelayanan online karena menghemat waktu pelaku usaha dalam melakukan administrasi perpajakan. Hasil penelitian ini sejalan dengan penelitian Sarunan (2015) menyatakan bahwa sistem pelayanan online berpengaruh positif dan signifikan terhadap kepatuhan wajib pajak.

Pengujian hipotesis ketiga dan keempat dilakukan dengan Moderated Regression Analysis (MRA). Hasil pengujian dapat dilihat pada Tabel 5, sebagai berikut.

Tabel 5. Hasil Uji Regresi Moderasi I

\begin{tabular}{|c|c|c|c|}
\hline Model & Nilai Beta & Signifikansi & Keterangan \\
\hline (Constant) & 43,069 & 0,081 & \\
\hline Penurunan Tarif Pajak & $-1,690$ & 0,017 & \\
\hline Pelayanan Online & 0,319 & 0,769 & \\
\hline Pemahaman Perpajakan & $-0,483$ & 0,275 & \\
\hline $\begin{array}{l}\text { Interaksi antara Penurunan Tarif Pajak } \\
\text { dan Pemahaman Perpajakan }\end{array}$ & 0,040 & 0,002 & $\begin{array}{c}\text { Mampu } \\
\text { Memperkuat }\end{array}$ \\
\hline $\begin{array}{l}\text { Interaksi antara Pelayanan Online dan } \\
\text { Pemahaman Perpajakan }\end{array}$ & $-0,002$ & 0,933 & $\begin{array}{c}\text { Tidak } \\
\text { mampu } \\
\text { memoderasi }\end{array}$ \\
\hline
\end{tabular}

Sumber: Data Penelitian, 2020

Hipotesis ketiga menyatakan bahwa pemahaman perpajakan memperkuat pengaruh penurunan tarif pajak pada kepatuhan wajib pajak. Dilihat dari nilai signifikansi interaksi penurunan tarif pajak dan pemahaman perpajakan sebesar 0,002 lebih kecil dari $a=0,05$ menunjukkan bahwa pemahaman perpajakan mampu memoderasi pengaruh penurunan tarif pajak pada kepatuhan wajib pajak. Nilai beta interaksi penurunan tarif pajak dan pemahaman perpajakan yang bernilai 0,040 menunjukkan bahwa pemahaman perpajakan memperkuat 
pengaruh penurunan tarif pajak pada kepatuhan wajib pajak, maka dari itu hipotesis ketiga diterima.

Hubungan variabel pemahaman perpajakan dengan variabel dependen dapat dilihat dari nilai signifikansi variabel pemahaman perpajakan sebesar 0,275 , lebih besar dari $a=0,05$. Sedangkan interaksi variabel pemahaman perpajakan dengan variabel independen dapat dilihat dari nilai signifikansi interaksi variabel penurunan tarif pajak dengan variabel pemahaman perpajakan yaitu sebesar 0,002, lebih kecil dari $a=0,05$. Dengan memperhatikan pengaruh langsung variabel moderasi dengan variabel dependen, dan interaksi antara variabel independen dengan variabel moderasi, maka variabel pemahaman perpajakan digolongkan kedalam jenis moderasi asli atau pure moderator. Pure moderasi tidak berfungsi sebagai variabel prediktor (independen) melainkan langsung berinteraksi dengan variabel prediktor lainnya.

Hasil penelitian ini mendukung teori atribusi menjelaskan bahwa ketika individu mengamati perilaku individu lainnya, individu tersebut berupaya untuk menjelaskan apakah perilaku tersebut disebabkan pihak internal ataupun eksternal (Robbins \& Judge, 2008). Perilaku yang disebabkan secara internal merupakan perilaku yang berada pada tingkah laku pribadi seorang individu sendiri, yang dalam penelitian ini dikaitkan dengan pemahaman perpajakan. Pemahaman perpajakan menjadi salah satu faktor yang mempengaruhi kepatuhan Wajib Pajak (Ananda et al., 2015). Fahluzy \& Agustina (2014) mendefinisikan pemahaman sebagai keadaan di mana wajib pajak mengerti dengan baik semua hal tentang perpajakan. Sehingga, apabila tingkat pemahaman perpajakan yang dimiliki tinggi, maka tingkat kepatuhan wajib pajak juga akan semakin meningkat.

Berdasarkan jawaban responden terhadap kuesioner penelitian "Seorang wajib pajak harus memiliki NPWP" menunjukkan bahwa Wajib Pajak UMKM memiliki pemahaman akan sarana administrasi perpajakan yaitu Nomor Pokok Wajib Pajak (NPWP). Hal tersebut ditunjukkan dengan nilai skor rata-rata tertinggi yaitu 4,92 terhadap pernyataan tersebut. Berdasarkan hasil penelitian, pemerintah dalam hal ini Direktorat Jendral Pajak (DJP) harus lebih mengiatkan sosialisasi tentang pemahaman perpajakan. Hal ini berguna karena kurangnya kesadaran wajib pajak dalam membayar pajak, tidak terlepas dari faktor pegetahuan dan pemahaman tentang perpajakan itu sendiri.

Hipotesis keempat menyatakan bahwa pemahaman perpajakan memperkuat pengaruh pelayanan online pada kepatuhan wajib pajak. Tabel 5 menunjukkan bahwa nilai signifikansi interaksi pelayanan online dan pemahaman perpajakan sebesar 0,933 yaitu lebih besar dari nilai $a=0,05$ menunjukkan bahwa variabel pemahaman perpajakan tidak mampu memoderasi pengaruh pelayanan online pada kepatuhan wajib pajak. Berdasarkan hasil uji tersebut maka hipotesis keempat ditolak.

Dilihat dari pengaruh langsung variabel moderasi, dan interaksi antara variabel independen dengan variabel moderasi, pemahaman perpajakan termasuk kedalam jenis moderasi potensial atau homologiser moderator. Hal tersebut dilihat dari nilai signifikansi variabel pemahman perpajakan yaitu 0,275 lebaih besar dari $a=0,05$, serta dilihat dari nilai signifikansi interaksi variabel pelayanan online dan pemahaman perpajakan yaitu 0,933 , lebih besar dari $\alpha=$ 
0,05. Nilai tersebut menunjukkan bahwa variabel pemahaman perpajakan sebagai variabel moderasi tidak berinteraksi dengan variabel independen dan tidak berhubungan secara signifikan dengan variabel dependen. Moderasi potensial atau homologiser moderator artinya bahwa variabel pemahaman perpajakan memiliki potensial menjadi variabel moderasi.

Hasil penelitian ini tidak mendukung pernyataan Nugraheni \& Purwanto (2015) yang menyatakan masih kurangnya kesadaran wajib pajak dalam membayar pajak, tidak terlepas dari faktor pegetahuan dan pemahaman tentang perpajakan itu sendiri. Penelitian yang dilakukan oleh Andayani et al., (2019) menunjukkan kesadaran wajib pajak tidak berpengaruh terhadap kepatuhan wajib pajak. Responden memiliki kesadaran akan kewajiban membayar pajak, namun tidak serta merta membuat patuh bayar pajak. Salah satu indikator dari pemahaman perpajakan dalam penelitian ini adalah sanksi perpajakan. Penelitian Lazuardini et al. (2019) yang menyatakan pada realita hasil perhitungan data primer, sanksi pajak berpengaruh negatif dan tidak signifikan terhadap ketaatan wajib pajak UMKM. Berdasarkan jawaban responden terhadap kuesioner penelitian "Wajib pajak yang mengalami keterlambatan bayar akan dikenakan penagihan pajak" dengan nilai skor rata-rata terendah yaitu 3,99 terhadap pernyataan tersebut menunjukkan bahwa Wajib Pajak UMKM tidak memiliki pemahaman akan kesadaran dari sanksi atas keterlambatan pembayaran pajak. Sehingga, pemahaman yang kurang akan sanksi perpajakan ini yang tidak dapat meningkatkan pengaruh pelayanan online pada kepatuhan wajib pajak. Walaupun telah diberikan kemudahan menggunakan pelayanan online, tetapi pemahaman tentang sanksi perpajakan yang dimiliki UMKM tersebut kurang sehingga tidak mampu meningkatkan kepatuhan wajib pajak UMKM.

Pengujian hipotesis kelima dan keenam dilakukan dengan Moderated Regression Analysis (MRA). Hasil pengujian dapat dilihat pada Tabel 6, sebagai berikut.

Tabel 6. Hasil Uji Regresi Moderasi II

\begin{tabular}{lccc}
\hline \multicolumn{1}{c}{ Model } & Nilai Beta & Signifikansi & Keterangan \\
\hline (Constant) & 18,738 & 0,236 & \\
Penurunan Tarif Pajak & $-0,763$ & 0,110 & \\
Pelayanan Online & 0,602 & 0,418 & \\
Religiusitas & 0,157 & 0,790 & \\
$\begin{array}{l}\text { Interaksi antara Penurunan Tarif Pajak } \\
\text { dan Religiusitas }\end{array}$ & 0,047 & 0,011 & $\begin{array}{c}\text { Mampu } \\
\text { Interaksi antara Pelayanan Online dan }\end{array}$ \\
$\begin{array}{l}\text { Religiusitas } \\
\text { Tidak }\end{array}$ \\
\hline
\end{tabular}

Sumber: Data Penelitian, 2020

Hipotesis kelima menyatakan bahwa religiusitas memperkuat pengaruh penurunan tarif pajak pada kepatuhan wajib pajak. Dilihat dari nilai signifikansi interaksi penurunan tarif pajak dan religiuistas sebesar 0,011 lebih kecil dari $a=$ 0,05 menunjukkan bahwa religiusitas mampu memoderasi pengaruh penurunan tarif pajak pada kepatuhan wajib pajak. Nilai beta interaksi penurunan tarif pajak dan religiusitas yang bernilai 0,047 menunjukkan bahwa religiusitas 
memperkuat pengaruh penurunan tarif pajak pada kepatuhan wajib pajak, maka dari itu hipotesis kelima diterima.

Hubungan variabel religiusitas dengan variabel dependen dapat dilihat dari nilai signifikansi variabel religiusitas sebesar 0,790, lebih besar dari $a=0,05$. Sedangkan interaksi variabel religiusitas dengan variabel independen dapat dilihat dari nilai signifikansi interaksi variabel penurunan tarif pajak dengan variabel religiusitas yaitu sebesar 0,011, lebih kecil dari $a=0,05$. Dengan memperhatikan pengaruh langsung variabel moderasi dengan variabel dependen, dan interaksi antara variabel independen dengan variabel moderasi, maka variabel pemahaman perpajakan digolongkan kedalam jenis moderasi asli atau pure moderator. Pure moderasi tidak berfungsi sebagai variabel prediktor (independen) melainkan langsung berinteraksi dengan variabel prediktor lainnya.

Hasil penelitian ini mendukung teori atribusi menjelaskan tentang individu yang mengamati perilaku individu lainnya, individu tersebut berupaya untuk menjelaskan apakah perilaku tersebut disebabkan pihak internal ataupun eksternal. Perilaku yang disebabkan secara internal merupakan perilaku yang berada pada tingkah laku pribadi seorang individu sendiri, yang dalam penelitian ini dikaitkan dengan religiuisitas. Menurut Utama \& Wahyudi (2016) dan Benk et al. (2016) menyatakan bahwa kepatuhan wajib pajak dipengaruhi oleh religiusitas. Semua agama di dunia ini memberikan petunjuk yang baik bagi pemeluk agamanya dengan menganjurkan untuk berperilaku yang baik dan mematuhi norma norma yang berlaku. Sehingga, tingkat religiusitas yang dimiliki seseorang ini berusaha berperilaku sesuai dengan kaidah norma yang berlaku. Sehingga, apabila religiusitas yang dimiliki tinggi, maka tingkat kepatuhan wajib pajak juga akan semakin meningkat karena wajib pajak UMKM akan mengikuti kaidah norma yang berlaku.

Berdasarkan jawaban responden terhadap kuesioner penelitian "Kepercayaan saya terhadap agama mempengaruhi saya dalam mengambil keputusan dalam hidup" dengan nilai skor rata-rata tertinggi yaitu 4,45 terhadap pernyataan tersebut. Hal ini menunjukkan bahwa Wajib Pajak UMKM memiliki kepercayaan akan agama dalam setiap pengambilan keputusan yang dilakukan di dalam hidup. Religiusitas merupakan keyakinan yang dimiliki seseorang yang didasari atas kepercayaan yang selalu ia tanamkan dalam dirinya, keyakinan yang membuat seseorang taat dan patuh dalam menjalankan kewajibannya terhadapa sesuatu hal yang wajib ia taati dan mematuhinya. Salah satu kewajiban dari wajib pajak adalah kewajiban untuk memenuhi kewajiban perpajakan yaitu kewajiban membayar pajak dan kewajiban melaporkan pajak. Wajib pajak yang religious berusaha untuk mematuhi norma dan aturan yang berlaku (Mayasari et al., 2015). Hasil penelitian ini senada dengan hasil penelitian Benk et al. (2016), Mayasari et al. (2015), dan Utama \& Wahyudi (2016) memberikan hasil bahwa seseorang yaitu wajib pajak yang memiliki tingkat kepercayaan yang tinggi, akan selalu senantiasa taat dan patuh terhadap kewajibannya terhadap peraturan perpajakan. Dengan adanya religiusitas yang tinggi dan penurunan tarif pajak akan mampu meningkatkan kepatuhan wajib pajak UMKM karena penurunan tarif pajak yang disertai dengan motivasi dari 
dalam diri wajib pajak yaitu kepercayaan yang dimiliki akan menuntun untuk menaati norma yang berlaku.

Hipotesis keenam menyatakan bahwa religiusitas memperkuat pengaruh pelayanan online pada kepatuhan wajib pajak. Tabel 6 menunjukkan bahwa nilai signifikansi interaksi pelayanan online dan religiusitas sebesar 0,436 yaitu lebih besar dari nilai $a=0,05$ menunjukkan bahwa variabel religiusitas tidak mampu memoderasi pengaruh pelayanan online pada kepatuhan wajib pajak. Berdasarkan hasil uji tersebut maka hipotesis keenam ditolak.

Dilihat dari pengaruh langsung variabel moderasi, dan interaksi antara variabel independen dengan variabel moderasi, religiusitas termasuk kedalam jenis moderasi potensial atau homologiser moderator. Hal tersebut dilihat dari nilai signifikansi variabel religiusitas yaitu 0,790 lebih besar dari $a=0,05$, serta dilihat dari nilai signifikansi interaksi variabel pelayanan online dan religiusitas yaitu 0,436 , lebih besar dari $\alpha=0,05$. Nilai tersebut menunjukkan bahwa variabel pemahaman perpajakan sebagai variabel moderasi tidak berinteraksi dengan variabel independen dan tidak berhubungan secara signifikan dengan variabel dependen. Moderasi potensial atau homologiser moderator artinya bahwa variabel religiusitas memiliki potensial menjadi variabel moderasi.

Hasil penelitian ini tidak mendukung pernyataan Utama \& Wahyudi (2016) yang menyatakan bahwa ketika wajib pajak yang memiliki religiusitas yang tinggi, maka ia berusaha untuk patuh terhadap peraturan perpajakan. Responden memiliki kepercayaan yang selalu ia tanamkan dalam dirinya, namun tidak serta merta membuat seseorang taat dan patuh dalam menjalankan kewajibannya, khususnya kewajiban perpajakan. Hal ini terlihat dari jawaban responden akan indikator keyakinan yang membuat seseorang taat dan patuh dalam menjalankan kewajibannya. Berdasarkan jawaban responden terhadap kuesioner penelitian "Saya merasa berdosa apabila melakukan kecurangan yang berkaitan dengan pajak" dengan nilai skor rata-rata terendah yaitu 3,92 terhadap pernyataan tersebut menunjukkan bahwa Wajib Pajak UMKM tidak merasa berdosa ketika melakukan kecurangan yang berkaitan dengan pajak yang berimplikasi pada tidak meningkatnya pengaruh pelayanan online pada kepatuhan wajib pajak. Walaupun telah diberikan kemudahan menggunakan pelayanan online, tetapi tidak ada perasaan berdosa yang dimiliki oleh wajib pajak UMKM menyebabkan religiusitas tidak mampu meningkatkan kepatuhan wajib pajak UMKM walaupun telah didukung dengan fasilitas pelayanan online untuk mempermudah administrasi perpajakan.

\section{SIMPULAN}

Berdasarkan hasil dan pembahasan, maka dapat disimpulkan bahwa Pertama, penurunan tarif pajak berpengaruh positif pada kepatuhan wajib pajak. Hal tersebut menunjukkan semakin tinggi penurunan tarif pajak maka kepatuhan wajib pajak akan semakin tinggi. Kedua, pelayanan online berpengaruh positif pada kepatuhan wajib pajak. Hal tersebut menunjukkan semakin tinggi pelayanan online maka kepatuhan wajib pajak akan semakin tinggi. Ketiga, pemahaman perpajakan mampu memperkuat pengaruh penurunan tarif pajak pada kepatuhan wajib pajak. Hal tersebut menunjukkan bahwa semakin tinggi pemahaman perpajakan yang dimiliki oleh wajib pajak, maka semakin tinggi 
kepatuhan wajib pajak tersebut saat wajib pajak mendapat fasilitas penurunan tarif perpajakan. Keempat, pemahaman perpajakan tidak mampu memoderasi pengaruh pelayanan online pada kepatuhan wajib pajak. Hal ini menunjukkan bahwa pemahaman perpajakan tidak memiliki pengaruh terhadap hubungan pelayanan online dengan kepatuhan wajib pajak. Kelima, religiusitas mampu memperkuat pengaruh penurunan tarif pajak pada kepatuhan wajib pajak. Hal tersebut menunjukkan bahwa semakin tinggi persepsi religius yang dimiliki oleh wajib pajak, maka semakin tinggi kepatuhan wajib pajak tersebut saat wajib pajak mendapat fasilitas penurunan tarif perpajakan. Keenam, religiusitas tidak mampu memoderasi pengaruh pelayanan online pada kepatuhan wajib pajak. Hal ini menunjukkan bahwa religiusitas tidak memiliki pengaruh terhadap hubungan pelayanan online dengan kepatuhan wajib pajak.

\section{REFERENSI}

Adiasa, N. (2013). Pengaruh Pemahaman Peraturan Pajak Terhadap Kepatuhan Wajib Pajak Dengan Moderating Preferensi Risiko. Accounting Analysis Journal, 2(3), 345-352. https:// doi.org/10.15294/aaj.v2i3.2848

Ajzen, I. (1991). The theory of planned behavior. Organizational Behavior and Human Decision Processes. https:/ / doi.org/10.1016/0749-5978(91)90020-T

Ajzen, I., \& Fishbein, M. (2005). The influence of attitudes on behaviour. The Handbook of Attitudes.

Ananda, P. R. D., Kumandji, S., \& Husaini, A. (2015). Pengaruh Sosialisasi Perpajakan, Tarif Pajak, dan Pemahaman Terhadap Kepatuhan Wajib Pajak (Studi pada UMKM yang Terdaftar sebagai Wajib Pajak di Kantor Pelayanan Pajak Pratama Batu). Jurnal Perpajakan (JEJAK), 6(2), 1-9. https://doi.org/10.1145/3132847.3132886

Andayani, E., Prasetyo, A., \& Yusuf, M. (2019). Faktor-Faktor Pelaksanaan PP 23 Tahun 2018 Terhadap Kepatuhan Wajib Pajak UMKM di Jakarta dengan Kesadaran Wajib Pajak sebagai Variabel Intervening. Eksekutif, 16(2), 187214. jurnal.ibmt.ac.id

Anggraeni, L. A. (2016). Pengaruh Kesadaran Wajib Pajak, Lingkungan Wajib Pajak, Sikap Religiusitas Wajib Pajak, dan Kemanfaatan NPWP Terhadap Kepatuhan Wajib Pajak (Studi Empiris pada Wajib Pajak Orang Pribadi yang Terdaftar di Kantor Pelayanan Pajak Pratama Klaten ). Naskah Publikasi, 1, 1-25.

Anwar, R. A., \& Syafiqurrahman, M. (2016). Pengaruh Sosialisasi Perpajakan Terhadap Kepatuhan Perpajakan Wajib Pajak Usaha Mikro Kecil Dan Menengah (Umkm) Di Surakarta Dengan Pengetahuan Perpajakan Sebagai Variabel Pemediasi. Jurnal InFestasi, 12(1), 66-74. https://doi.org/10.21107/infestasi.v12i1.1801

Ayem, S., \& Nofitasari, D. (2019). Pengaruh Sosialisasi PP No. 23 Tahun 2018, Modernisasi Sistem Administrasi Perpajakan, Dan Biaya Kepatuhan Terhadap Kemauan Membayar Pajak Pada Pada Wajib Pajak Umkm. Akuntansi Dan Governance Andalas, 2(23), 105-121.

Basri, Y. M., \& Surya, R. A. S. (2014). Pengaruh Keadilan, Norma Ekspektasi, Sanksi Dan Religiusitas Terhadap Niat Dan Ketidak Patuhan Pajak. 


\section{Akuntabilitas, 7(3), 162-176. https:/ / doi.org/10.15408/akt.v7i3.2733}

Benk, S., Budak, T., Yuzbasi, B., \& Mohdali, R. (2016). The Impact of Religiosity on Tax Compliance among Turkish Self-Employed Taxpayers. Religions, 7(37), 1-10. https:/ / doi.org/10.3390/rel7040037

Campin, S., Barraket, J., \& Luke, B. (2013). Micro-Business Community Responsibility in Australia: Approaches, Motivations and Barriers. Journal of Business Ethics, 115(3), 489-513. https:// doi.org/10.1007/s10551-012-1396-1

Chen, D., Lee, F. C., \& Mintz, J. (2002). Taxation , SMEs and Entrepreneurship. STI Working Paper, 1-48.

Eagly, A. H., \& Chaiken, S. (2007). The advantages of an inclusive definition of attitude. Social Cognition. https:// doi.org/10.1521/soco.2007.25.5.582

Fahluzy, S. F., \& Agustina, L. (2014). Faktor-Faktor Yang Mempengaruhi Kepatuhan Membayar Pajak Umkm Di Kabupaten Kendal. Accounting Analysis Journal, 3(3), 399-406. https:// doi.org/10.15294/aaj.v3i3.4222

Gunawan, T., Suprapti, E., \& Kurniawati, E. T. (2014). Persepsi Wajib Pajak Mengenai E-Filing dan Pengaruhnya terhadap Tingkat Kepatuhan Wajib Pajak Orang Pribadi Dalam Melaporkan Pajak. Jurnal Reviu Akuntansi Dan Keuangan, 4(2), 615-622. https://doi.org/10.22219/jrak.v4i2.4947

Hendricks, K., Amit, R., \& Whistler, D. (1997). Business Taxation of Small and Medium-sized Enterprises in Canada. Ottawa: Department of Finance Working Paper, 1-48.

Kamleitner, B., Korunka, C., \& Kirchler, E. (2012). Tax Compliance of Small Business Owners: A Review. International Journal of Entrepreneurial Behaviour and Research, 18(3), 330-351. https:/ / doi.org/10.1108/13552551211227710

Kementerian Keuangan Republik Indonesia. (2019). Media Keuangan Transparansi Informasi Kebijakan Fiskal: Vol. XIV (Issue 138).

Kementrian dan Koperasi dan Usaha Mikro Kecil dan Menengah Republik Indonesia. (2019). Perkembangan Data Usaha Mikro, Kecil, Menengah Dan Usaha Besar.

Lazuardini, E. R., Susyanti, J., \& Priyono, A. A. (2019). Pengaruh Pemahaman Peraturan Perpajakan, Tarif Pajak Dan Sanksi Pajak Terhadap Kepatuhan Wajib Pajak UMKM (Studi Pada Wajib Pajak Orang Pribadi Yang Terdaftar di KPP Pratama Malang Selatan). E - Jurnal Riset ManajemenPRODI MANAJEMEN, 25-34. jurnal.ibmt.ac.id

Mayasari, W., Zaitul, \& Muslim, R. Y. (2015). Pengaruh Ketaatan Beragama Terhadap Moral Pajak. Fakultas Ekonomi Universitas Bung Hatta, April 2015, 1-13.

Mir'atusholihah, Kumadji, S., \& Ismono, B. (2014). Pengaruh Pengetahuan Perpajakan, Kualitas Pelayanan Fiskus, dan Tarif Pajak Terhadap Kepatuhan Wajib Pajak (Studi Pada Wajib Pajak UMKM di Kantor Pelayanan Pajak Pratama Malang Utara). Jurnal Mahasiswa Perpajakan, 3(1), $1-10$.

Molero, J. C., \& Pujol, F. (2012). Walking Inside the Potential Tax Evader's Mind: Tax Morale Does Matter. Journal of Business Ethics, 105(2), 151-162. https:/ / doi.org/10.1007/s10551-011-0955-1

Mustofa, F. A., Kertahadi, \& Maulinarhadi, M. (2016). Pengaruh Pemahaman 
Peraturan Perpajakan, Tarif Pajak, Dan Asas Keadilan Terhadap Kepatuhan Wajib Pajak. Jurnal Perpajakan (JEJAK), 8(1), 1-7. https://doi.org/10.35829/econbank.v1i1.7

Nadhor, K., Fatoni, N., Nurudin, \& Zakiy, F. S. (2020). Pengaruh Penurunan Tarif Pajak UMKM dan Sistem Pelayanan Online Terhadap Persepsi Wajib Pajak (Studi Pada UMKM Yang Terdaftar di KPP Semarang Barat). EL MUHASABA, 11(1), 88-113.

Nugraheni, A. D., \& Purwanto, A. (2015). Faktor-Faktor yang Mempengaruhi Kepatuhan Wajib Pajak Orang Pribadi (Studi Empiris Pada Wajib Pajak di Kota Magelang). Diponegoro Journal of Accounting, 4(3), 1-14.

Oladipupo, A. O., \& Obazee, U. (2016). Tax Knowledge, Penalties and Tax Compliance in Small and Medium Scale Enterprises in Nigeria. IBusiness, 08(01), 1-9. https:// doi.org/10.4236/ib.2016.81001

Praag, C. M. Van, \& Versloot, P. H. (2007). What is the value of entrepreneurship? A review of recent research. Small Business Economics, 29(4), 351-382. https:// doi.org/10.1007/s11187-007-9074-x

Prawagis, F. D., Zahroh, \& Mayowan, Y. (2016). Pengaruh Pemahaman atas Mekanisme Pembayaran Pajak, Persepsi Tarif Pajak dan Sanksi Pajak terhadap Kepatuhan Wajib Pajak UMKM (Studi Pada Wajib Pajak Yang Terdaftar di KPP Pratama Batu). Jurnal Perpajakan (JEJAK), 10(1), 1-8.

Rachdianti, F. T., Astuti, E. S., \& Susilo, H. (2016). Pengaruh Penggunaan E-Tax Terhadap Kepatuhan Wajib Pajak. Jurnal Perpajakan (JEJAK), 11(1), 1-7. https://doi.org/10.2991/aebmr.k.200305.001

Robbins, S. P., \& Judge, T. A. (2008). Perilaku Organisasi Jilid II. Salemba Empat.

Sari, P. V. A. (2017). Pengaruh Tax Amnesty, Pengetahuan Perpajakan, dan Pelayanan Fiskus Terhadap Kepatuhan Wajib Pajak. Jurnal Ilmu Dan Riset Akuntansi, 6(2), 744-760.

Sarunan, W. K. (2015). Pengaruh Modernisasi Sistem Administrasi Perpajakan Terhadap Kepatuhan Wajib Pajak Orang Pribadi dan Wajib Pajak Badan Pada Kantor Pelayanan Pajak Pratama Manado. Jurnal EMBA, 3(4), 518-526. https://doi.org/10.25273/jap.v4i2.683

Supadmi, N. L., \& Suputra, D. G. D. (2016). Persepsi Wajib Pajak atas Pemberlakuan Peraturan Pemerintah Nomor 46 Tahun 2013 dan Pengaruhnya pada Kepatuhan Perpajakan (Studi Kasus pada UMKM di Kota Denpasar). Jurnal Ilmiah Manajemen \& Akuntansi, 22(2), 95-107.

Utama, A., \& Wahyudi, D. (2016). Pengaruh Religiusitas terhadap Perilaku Kepatuhan Wajib Pajak Orang Pribadi di Provinsi DKI Jakarta. Jurnal Lingkar Widyaiswara, 3(2), 1-13. https://doi.org/10.1016/S00404020(00)00446-4

Widiasih, D. N., \& Wiagustini, N. L. P. (2019). Pengaruh Keadilan Pajak, Pengetahuan Pajak, Sanksi Pajak dan Konsultan Pajak Terhadap Kepatuhan Wajib Pajak Usaha Mikro Kecil Menengah Pada KPP Denpasar Barat. Journal of Applied Management Studies, 1(1), 29-38.

Yusro, H. W., \& Kiswanto. (2014). Pengaruh Tarif Pajak, Mekanisme Pembayaran Pajak Dan Kesadaran Membayar Pajak Terhadap Kepatuhan Wajib Pajak 
Umkm Di Kabupen Jepara. Accounting Analysis Journal, 3(4), 429-436. https://doi.org/10.15294/aaj.v3i4.4201

Zelmiyanti, R., \& Suwardi, E. (2019). Dampak Moderasi Moral Perpajakan pada Hubungan Perceived Probability of Audit dan Sanksi terhadap Perilaku Kepatuhan Pajak Usaha Mikro, Kecil dan Menengah (UMKM) (Studi Empiris pada UMKM Daerah Istimewa Yogjakarta). Journal of Applied Accounting and Taxation, 4(1), 69-78. https:// doi.org/10.30871/jaat.v4i1.1097

Zuhdi, F. A., Topowijono, \& Azizah, D. F. (2015). Pengaruh Penerapan E-SPT dan Pengetahuan Perpajakan Terhadap Kepatuhan Wajib Pajak (Studi Pada Pengusaha Kena Pajak yang Terdaftar di KPP Pratama Singosari). Jurnal Perpajakan (JEJAK), 7(1), 1-7. https://doi.org/10.1007/978-3-531-92674-2_11 